\title{
討論の総括と今後の展望 教科書の書き換えは可能か?
}

\section{三成美保}

\section{1. 高校社会科教科書の現状} 現代社会と世界史

ジェンダー視点を欠く歴史教育は、二重の意 味で、ゆがんだ歴史イメージを人びとに与える。 第一に、男性だけが歴史の主体であるかのよう な䛊解を生じさせる。第二に、近代歴史学の誕 生以降、「私的領域/女性領域」とみなされて 歴史叙述の周縁におかれてきた社会現象に関 する知識が培われない。歴史教育にジェンダー 視点を取り込むとは、単に女性への言及を増や すだけで事足りるのではない。生活、家族、性 と生殖といった人間社会の根本に関わる歴史 に目を向けることである。

教科書の現状はどうか。高校の社会科教科書 のうち、公民系ではどの教科書も男女雇用機会 均等法や男女共同参画社会基本法に言及して いる。違いは、そのさいに「ジェンダー」と いう言葉をあげているかどうかである。とく に現代社会には、本文ゴシック体でジェンダー という語を掲げているものが多い。たとえば、 混合名簿・生徒会・運動競技などを例に挙げ て「男女にふり分けられている性役割には、社 会的・文化的につくられたジェンダーによるも のが少なくない」と記し、基本法の英語訳が gender equalityであるとの注を付す (三省堂)、 経済を論じる編の冒頭見開き 2 頁を使って「働 く場での男女平等をめざして」とうたい、「ジェ ンダー問題」として参政権・D V ・ セクハラ・
世界女性会議等を総合的に論じる（数研出版）、 キーワードとしてジェンダーと男女共同参画 をあげ、ジェンダー・エンパワーメント指数を 示す表・育児取得状況比較表を掲げる（教育出 版）ほか、控えめな表現ながらもそれなりに言 及する (山川出版社) などである。

これに対し、本シンポジウム報告で指摘され たとおり、歴史教科書については女性史やジェ ンダー史への配慮はきわめてそしい。ジェン ダーという語も登場しない。しかし、変化の兆 しは確実にある。世界史について補足するなら ば、世界史 $\mathrm{A} ・ \mathrm{~B}$ とも大判でビジュアルを意識 し、社会史の成果を意識的に取り入れて生徒の 興味を引こうと努力している教科書には、ささ やかながらジェンダー史の成果が反映されて いるものがある（いずれも2006年検定以降の 教科書)。

世界史 Aの場合、注でオランプ・ド•グージュ に言及（三省堂・実教出版など）、見開き 2 頁 のコラム「女性の社会進出とファッション」(帝 国書院)、半頁強のコラム「ルイ14世をめぐる 女性」のなかで「女性は歴史の舞台の陰で歴史 を支えていた」と指摘（清水書院）、1頁のコ ラム「教育と女性」で「社会において公私の役 割が区別され、女性は私の領域、特に家族に対 する責任をおうことがしだいに強調されるよ うになった」と公私二分論にまで踏み込んだ言 及（東京書籍）などが目立つ。

世界史Bはかなり方向性が分かれる。Aより 
トピックを増やすタイプとコラムがほとんど なくオーソドックスな記述方法にとどまる夕 イプである（三省堂・実教出版）。前者には次 のようなものがある。コラム「生活と家族」「女 性参政権」のうち、後者で「どうして、教科書 に出てくる人物は圧倒的に男性であり、女性の 君主や政治家は少ないのだろうか。その理由の 一つは、政治など公の世界が男性の領域とされ てきたことにある」と問いかけ、公私二分論と 非対称な性別役割分担を指摘する（東京書籍）。 あるいは、ローマ家父長制・マリア崇择・女性 参政権を各1頁ずつコラムで取り上げる（清水 書院)、小さいコラムながら「女性と奴隷にとっ ての民主政」「市民社会と性別役割分担の定着」 を明記する（帝国書院）、コラム「女性と産業 革命」で近代的な性別役割分担の成立を指摘す る (山川出版社)、半ページ弱のコラム「女性 解放運動」でグージュとナポレオン法典の家父 長制に言及する（東京書籍：新選）、一般のコ ラムで子ども・グージュ・女性解放運動、人物 コラムで意識的に比較的多くの女性を取り上 げる（第一学習社）。

\section{2. 今後の課題一討論をふまえて}

以上のような現状に対し、教育現場と教科書 は具体的にどのように対処すべきか。フロアか らの質問もこの点に集中した。なかでも討論の 柱となったのは、次の 3 点である。（1）高校現 場の多忙化による教育の困難、（2）入試におけ
るジェンダー不在、（3）教科書書き直しの方向 性。以下では、討論に扔ける論点をまとめ、私 見を述べておきたい。

（1）高校の教育現場が直面している最大の困難 は、教育時間の圧倒的不足である。ただでさえ 足りない時間を「コラム扱いのジェンダー史」 に割くことは果たしてできるのか。この問いは、 二つの意味でジェンダー史の現状をよく反映 している。(1)歴史学におけるジェンダー史の位 置づけ、(2)受験対策としてのジェンダー史の扱 いである。

(1)ジェンダー史は、本来、歴史学を根底から 問い直す力を秘めている。にもかかわらず、現 状ではせいぜいコラムの補足事項としてしか 扱われない。アメリカの教科書と比べても改善 の余地は大きい（富永報告）。しかし、これは ジェンダー史そのものの限界ではない。日本に おけるジェンダー史研究の位置づけに原因が ある。そもそも、日本史は長い女性史の伝統を もち、ジェンダー史の取り込みも比較的早かっ たが、学界全体のなかでジェンダー史は周縁化 されてきだ。これを反映してか、日本史教科 書では女性を取り上げるものの、ジェンダー視 点を欠く傾向が強い（久留島報告・長野報告）。 他方、西洋史におけるジェンダー史の浸透は日 本史よりも遅れているが、公私二分論などの西 洋近代的ジェンダー・バイアスはいまや定番 コラムの趣を呈している。 女性やジェンダーへの配慮がもっともそしい。 2004年に日本でもジェンダー史学会が生まれ、 
研究は着実に進んでいる3 。検定制度のもとで 最先端の研究成果を教科書に反映する手立て としてコラムを積極的に位置づけることは無 意味ではない。

(2)ジェンダー史は問題発見機能をもち、「考 える歴史」を指向する。その限りでは、現行の ような暗記型入試問題には不向きである。しか し、ジェンダー史にむけられるとまどいの原因 はおそらくそこにあるのではない。現状のコラ ムの大半はジェンダー史としては不十分で、人 名や事件・事項の紹介にとどまっている。それ は暗記事項を増やすだけである。ジェンダー史 の本領発揮は、政治・経済のさまざまな事項を 意外な視点でつなぐことにある。それは本文主 体の受験対策と決して矛盾しない。

（2）大学入試については、二点が指摘された。 (1)入試問題作成教員のジェンダー・バイアス、 (2)高校歴史教育・入試・大学教養の歴史教育の 連携である。

(1)入試問題作成にあたる大学の歴史学教員 の多くが男性であり、ジェンダー史への関心も さほど強くない。高校への働きかけをする前に、 まず大学教員のジェンダー・バイアスを改める べきという意見はもっともである。

(2)現状では、ジェンダー史の教育や出題は、 担当者の関心 ・能力によって大きく左右されて いる。教育の質・内容に大きな差をもうけるこ となく効果的な歴史教育を行うためには、中学. 高校・大学（教養）の歴史教育を整合的に組み 立て直すことが必要であろう。そのための連絡

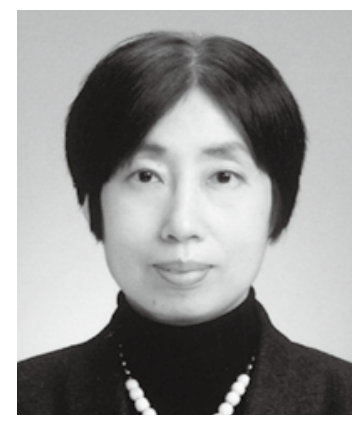

\section{PROFILE}

三成美保

(みつなり みほ)

日本学術会議連携会員、摂南大学法 学部教授

専門：西洋法制史・ジェンダー法学
機関の制度化が急務である。歴史を身近にする には、たとえば、中学で全体史を意識した社会 史・ジェンダー史から入り、高校で政治史・経 済史・国際関係史に移り、大学教養では複数の 歴史科目のなかから関心をもつ分野を重点的 に学ぶという方法もありえよう。

（3）もっとも本質的な課題である教科書の書き 換えには、三つの方向が考えられる。(1)ジェン ダー史の内容を盛り込み、コラム等の充実をはか る。(2)既存の政治史・経済史の項目の一部をジェ ンダー史に入れ替える。(3)ジェンダー視点にもと づいて教科書の項目・文面を全面改訂する。

長期的展望として目指されるべきは、「(3)全 面改訂」である。それは、「男性史」にすぎな い教科書の叙述を「女性史」に書き換えること を意味するのではない。ジェンダー史は、人間 社会のさまざまな「差異化」（差別・抑圧・支 配など）に目配りをしつつ、男女双方を含む多 様な人びとの生活に根ざした社会構造を明ら かにしようとする。教科書であればこそ、特定 の性に叙述が偏っていてはならない。

「1)コラム」は、先述の通り、すでに着手さ れている。ただし現状では、世界史の場合、西 
洋史の特定トピック（フランス革命・近代家族・ フェミニズム・女性参政権など）に事例が限ら れている。コラム項目の増加・内容の深化が望 まれる。奴隷制（井野瀬報告）・性と生殖（荻 野報告）などは格好のコラム素材となろう。そ のさい、「授業での説明は省く場合もある」と の前提にたち、単元ごとに 1 2 頁程度のジェ ンダー史的なコラムやトピックを盛り込むの が現実的である。本文の素っ気ない歴史叙述に 人間生活の豊かな息吹を盛り込む手段として ジェンダー史を活用すれば、歴史への興味を存 分にかき立てることができよう。

「(2)本文の一部改訂」の可能性も大いに開か れている。たとえば、ジェンダー史は古代ギリ シア民主政のイメージを大きく修正する（桜井 報告)。

結論として言うならば、「(3)全面改訂」を視 野に収めつつ、当面は社会史的記述の充実と歩 調をあわせて、「(1)コラム」の項目拡張をはか り、「(2)本文の一部改訂」で書き換えるべき項 目を徐々に増やしていくことが肝要だと思わ れる。多忙化著しい高校教師が手軽にアクセス できるように、サブテキストやウェブ情報の提 供も必要であろう。また、コミック（藤本報告） に代表されるサブカルチャーやミュージアム 展示企画（香川報告）などとの連携も積極的に はかられるべきである。

本シンポジウムを通して、多くの課題が明ら かになった。討論の成果をふまえ、本分科会は 次年度の課題として、サブテキストづくりの可
能性を検討する予定である 4

注

1 長野ひろ子『ジェンダー史を学ぶ』吉川弘文館、2006 年。

2 三成美保「学界展望『ジェンダー史』の課題と展望」『西 洋史学』229 号、2008 年、同『ジェンダーの法史学一近 代ドイツの家族とセクシュアリティ』勁草書房、2005 年。

3 たとえば、姫岡とし子・川越修編『ドイツ近現代ジェンダー 史入門』青木書店、2009 年。

4 『ふえみん』揭載予定の姫岡とし子によるシンポジウム総括も 参照のこと。 